\title{
Their Fault, Not Mine: Religious Commitment, Conservatism, and Americans' Retrospective Reasons for Divorce
}

\author{
Samuel L. Perry, University of Oklahoma \\ samperry@ou.edu
}

\begin{abstract}
How does religion influence the ways divorcées frame their divorce experience? Building on Mills's "vocabularies of motive" concept, I theorize that Americans who are more religious or affiliated with a conservative Protestant tradition will be more likely to emphasize their formerspouse's role in the divorce while minimizing their own. Data are taken from a large, representative sample of divorced Americans in the 2014 Relationships in America survey. Analyses affirm that divorced Americans who attend worship services more frequently are more likely to say that their former-spouse wanted the divorce more than they did. Looking at 17 specific reasons for divorce, those who feel religion is more important to them are consistently more likely to select reasons that put blame on their former-spouse or circumstances, while frequent attendees are less likely to cite their own behaviors or intentions. Though less consistent, notable patterns emerged for conservative Protestants as well. Given the stigma against divorce in many religious communities, I argue that divorcées in such communities likely feel internal pressure to account for their divorce in ways that deflect blame.
\end{abstract}

Key words: evangelicals, marriage, divorce, religious attendance, vocabularies of motive 


\section{Introduction}

A vast literature has explored the relationship between religion and marital stability, with studies consistently showing that divorce is less common among Americans who are more religious (Amato and Rogers 1997; Brown, Orbuch, and Bauermeister 2008; Bulanda and Brown 2007; Call and Heaton 1997; Chi and Houseknecht 1985; Glenn and Supancic 1984; Lehrer and Chiswick 1993; Massoglia, Remster, and King 2011) and hold theologically conservative beliefs (Call and Heaton 1997; Vaaler, Ellison, and Powers 2009; but see Glass and Levchak 2014). This is often attributed to the stronger collective sanctions that conservative Christian communities have against divorce as well as their general sanctification of the marriage relationship (see reviews in Amato 2010; Lehrer and Son 2017; Mahoney 2010; Mahoney et al. 2001; Weaver et al. 2002). Yet despite all that we know about the religious correlates of divorce, we still know very little about the role religion plays in shaping the ways divorcées explain their divorce in hindsight. Do the retrospective accounts that devoutly-religious or theologically conservative Americans give for their divorce differ in predictable ways from those who are relatively less religious or conservative?

The answer to this question is not inconsequential. Divorce is an historically stigmatizing experience (Gerstel 1987). This has been especially true within many conservative faith communities where divorcées often report feeling marked socially (Konieczny 2016; Konstam et al. 2016; Sullivan 2012) while also grappling with internal shame (Jenkins 2010, 2014; Simonič and Klobučar 2017). Recognizing the ways religious factors might influence how divorced Americans publically account for their own divorce in retrospect would help us understand how Americans socially process-or even re-interpret-the experience of divorce in light of broader community sanctions. 
Drawing on data from a unique, large, and representative sample of divorced Americans, this study examines how religion potentially influences the retrospective reasons divorced men and women highlight as contributing to their divorce. Building on the "vocabularies of motive" concept articulated by C. Wright Mills (1940) and subsequent others (Burke 1969; Perry 2017a), I theorize that, because divorce is often stigmatized among conservative religious communities, divorced respondents who are more religious or affiliated with conservative Protestantism will be more likely to portray their divorce in ways that emphasize their former-spouse's faults and initiation in the event and less likely to blame themselves. Before proceeding with the analyses, however, the following section discusses the connection between religion and divorce and introduces the "vocabularies of motive" concept in order to theorize expectations about how religion shapes divorced Americans' retrospective accounts of their divorce.

\section{Background}

\subsection{Religion and Divorce in the United States}

Studies on the social correlates of marital stability find that individual religiosity (measured in a variety of ways) tends to be negatively-though often only weakly-associated with experiencing a divorce (Mahoney 2010). Focusing primarily on religious service attendance as an indicator of religious commitment, some studies have found a non-significant relationship between attendance and divorce (Vaaler et al. 2009), while most others find the two factors to be significantly correlated (Amato and Rogers 1997; Brown et al. 2008; Bulanda and Brown 2007; Clydesdale 1997; Massoglia, Remster, and King 2011; Perry 2018; Sweezy and Tiefenthaler 1996; Wilcox 2004; Wilcox and Wolfinger 2016). Importantly, the association could be bidirectional due to the religious stigma that divorced Americans often face in religious contexts. That is, people may simply be less likely to attend church after their divorce, just as religious 
attendance or commitment more generally may discourage divorce (Brown 2015; Konstam et al. 2016; Sullivan 2012). Even so, longitudinal studies of religion and divorce have shown that religious commitment does indeed seem to have a temporal, directional effect on the likelihood of divorce over time (Amato and Rogers 1997; Bulanda and Brown 2007; Perry 2018).

Despite the consistent association between religiosity and divorce, however, the link between theological beliefs or affiliation and divorce is less consistent. Several studies have found that affiliation with conservative Protestantism is either unassociated with divorce after controlling for relevant sociodemographic factors (Barna Group 2001, 2004; Call and Heaton 1997; Glenn and Supancic 1984; Wilcox 2009) or even positively associated with divorce, particularly in the aggregate (Chi and Houseknecht 1985; Glass and Levchack 2014; Mullins et al. 2006). Indeed, some studies suggest that the extreme pro-marriage norms espoused by theologically conservative religious communities actually indirectly increase marital dissolution by promoting earlier marriage and lower female education (Glass and Levchak 2014; Lehrer and Son 2017). Other studies, however, find that those in conservative Protestant traditions (Barna Group 2008; Gray 2013; Perry 2018; Sweezy and Tiefenthaler 1996) and those who otherwise hold conservative theological views (Lehrer and Chiswick 1993; Vaaler et al. 2009; but see Heaton and Pratt 1990) are generally less likely to be divorced than the irreligious. A number of studies also find that religious homogamy-marrying someone of similar faith tradition and/or commitment - also tends to be positively associated with married couples staying together (Call and Heaton 1997; Heaton and Pratt 1990; Lehrer and Chiswick 1993; Vaaler et al. 2009).

Explaining the connection between religion and divorce, those who find religiosity lessens the probability of divorce argue that devoutly religious individuals likely internalize their community's standards about the importance of marriage and the seriousness of marital 
dissolution (Lehrer 2004:709; Mahoney et al. 2001). Others suggest that religious communities likely also place social pressure on individuals to work through problems in marriage, condoning divorce only as a "last resort" (Jenkins 2005; Levitt and Ware 2006), often only for situations of abandonment or sexual infidelity (Gilkerson 2015; Van Biema 2007), and within some conservative Protestant camps not even then (Piper 2009). ${ }^{1}$ Both of these factors heighten the possibility that Americans within these religious communities will experience more acute internal and social consequences when divorce actually occurs.

\subsection{Religion and the Experiences of Divorcées}

Even though devoutly-religious, theologically conservative Americans tend to strongly oppose divorce in theory, members of these communities still experience divorce at rates at or just below those of other Americans (Glass and Levchack 2014; Wilcox and Wolfinger 2016). How do these men and women experience their divorce within these communities? Findings from qualitative, small-sample studies of divorcées consistently reveal that men and women often feel like their divorce stigmatizes them in the eyes of other believers. Despite the fact that clergy often report wanting their congregation to care for individuals experiencing family disruption (Edgell 2006; Jenkins 2014), these clergy are paradoxically often very vocal about defending the sanctity of marriage, and criticizing the surrounding "individualistic" American culture for its perceived devaluation of marriage (Jenkins 2005; Konieczny 2016). This can consequently convey the message that churchgoers who get divorced (regardless of circumstances) are selfish, broken, and/or unspiritual. For example, Jenkins’ (2010, 2014)

\footnotetext{
${ }^{1}$ For example, a well-known Baptist pastor and author, John Piper (2009:159) argues that because marriage is supposed to represent Christ and his church, and because Jesus would never divorce his church, the Bible, therefore, does not permit divorce for Christians under any circumstances: “... as long as Christ keeps his covenant with the church, and as long as the church, by the omnipotent grace of God, remains the chosen people of Christ, then the very meaning of marriage will include: What God has joined, only God can separate" (italics his).
} 
ethnographic and interview-based study of divorce within the context of congregations shows that divorced churchgoers often anticipated gossip and judgment from their fellow congregants, forcing them to grapple with social shame. This, in combination with the fact that divorce was rarely talked about in many congregations, heightened the isolation her respondents felt. Importantly, Jenkins also recounts how her interviewees, through religious rituals, engage in emotional self-work, creating a "new self" and re-imagining their lives in light of beliefs they chose to emphasize.

Elsewhere, Konstam et al.'s (2016) interview-based study of women experiencing divorce finds that both religious and irreligious women alike feared how those in certain religious communities would stigmatize then. Indeed, several noted being surprised when their own congregations proved more welcoming toward them then they had expected. Several others, however, felt that conservative anti-divorce beliefs not only inclined their religious communities to stigmatize their divorce, but were largely to blame for Western society's overall negative evaluation of divorcées. And most recently, Simonič and Klobučar’s (2017) exploratory, qualitative study of 11 divorced women reveals how personal spiritual practices allowed these women to combat feelings of isolation and shame by reinterpreting their experience, specifically, by seeing God as on their side, loving and strengthening them through their ordeal. These qualitative studies, though with relatively few participants, affirm that those in religious communities do indeed struggle with feelings of shame and perceived stigma, and a consistent theme in their accounts is the need to reinterpret or reimagine their situation in ways that attenuate feelings of dissonance or isolation. In the following section I consider Mills's (1940) "vocabularies of motive" concept in order to frame expectations about the ways religion may influence divorcées' accounts of their experience. 


\subsection{Vocabularies of Motive, Religion, and Retrospective Reasons for Divorce}

"Accounts" or explanations of motive, according to C. Wright Mills (1940; see also Burke 1969; Perry 2017a), serve an important social function in that they situate one's own behavior in a way that others can not only understand the reasons behind that behavior, but affirm them. Because such explanations serve a primarily social function, Mills proposed that sociologists should not think of motives as subjective "springs" from which action flows, but rather as standard vocabularies that situate action within defined social situations. Social actors give an "account" of their motives for specific reasons, and those reasons are usually because those accounts or "vocabularies of motive" are those that are socially condoned by a particular audience given the social situation. Different institutional situations call for different vocabularies of motive to account for certain lines of behavior. ${ }^{2}$ Indeed, Mills criticized the scholarly quest for "real motives" since he believed that such quests proceed from the faulty premise that real motives are something essential to the individual, which we cannot observe empirically. Rather, he proposed that social scientists are better served by analyzing vocabularies of motive to better understand the social situation in which such vocabularies are learned and expected. He concluded, "Rather than interpreting actions and language as external manifestations of subjective and deeper lying elements in individuals, the research task is the locating of particular types of action within typal frames of normative actions and socially situated clusters of motive" (Mills 1940:913).

\footnotetext{
${ }^{2}$ Importantly, Mills did not think of these socially-approved "accounts" as lies necessarily (though he acknowledges some might be lies), because he believed these vocabularies of motive were often internalized by the actor to genuinely shape their future action. For example, he explained, "The long acting out of a role, with its appropriate motives, will often induce a man to become what at first he merely sought to appear. [...] vocabularies of motives for different situations are significant determinants of conduct." (1940:908). And later, he writes, "To term [motives] justification is not to deny their efficacy. Often anticipations of acceptable justifications will control conduct. ('If I did this, what could I say? What would they say?') Decisions may be, wholly or in part, delimited by answers to such queries" (1940:907).
} 
In other words, the "accounts" or reasons people give for their behavior in retrospect tell us not only (or even primarily) about their actual motivations, but about the broader social milieu which required those specific reasons to justify the action socially. Religious adherents, for example, may tell an interviewer that they give alms to the poor out of genuine charity. Whether that is really their motive is not empirically observable. Thus, what is more instructive for social scientists, according to Mills, is the implication that the adherents' social community apparently requires alms-giving to be done with charitable motivations, and thus requires community members to account for that giving with the appropriate vocabularies of motive.

Mills's "vocabularies of motive" concept is useful for interpreting divorcées retrospective explanations for their divorce. It is impossible to discern whether a divorce happened precisely for the reasons that a divorced man or woman reports, potentially years after the fact. But this is not problematic if we understand retrospective "reasons" for a divorce using Mills's conceptual framework, namely, as "accounts" that social actors are providing to situate their behavior in a way that is consonant with their own self-concept and according to what are deemed to be appropriate reasons for divorce within their particular reference group. Different patterns of reasons for divorce, therefore, will inform our understanding of how different social contexts require different accounts to justify divorce.

Because deeply-religious, theologically conservative Americans are more likely to view divorce as sinful and stigmatizing, I expect that their retrospective reasons for their divorce will differ from others' in patterned, predictable ways. Specifically, I expect that divorcées who are more religious or affiliated with conservative Protestantism—the subculture most opposed to divorce (Ellison, Wolfinger, and Ramos-Wada 2012; Martin and Parashar 2006; Stokes and Ellison 2010)—will be more likely to (1) indicate that their former-spouse wanted the divorce 
more than they did, thus citing their former-spouse as the initiator, and (2) frame their divorce in ways that deflect blame from themselves and place the blame on their former-spouse's character or behavior. And while not the primary focus of this study, I also anticipate these reasons given for divorce to be somewhat gendered based on typical relationship patterns. For example, I expect that women will be more likely than men to express that they sought a divorce because of their former-spouse's physical abuse, obsession with their career, or pornography use, since these are less likely to be a cause for divorce among men.

\section{Methods}

\subsection{Data}

Data are taken from the 2014 Relationships in America (RIA) survey. The RIA survey was distributed to a national probability sample of 15,738 adults between the ages of 18 and 60 years old in January and February 2014. Data collection was sponsored by the Austin Institute for the Study of Family and Culture and conducted by the research firm GfK. GfK recruited the first online research "panel"3 that is representative of the US population, called the "KnowledgePanel." Members in the KnowledgePanel are randomly recruited by telephone and mail surveys. Those households are provided with access to the Internet and computer hardware if necessary. ${ }^{4}$ The main survey completion rate for the RIA survey instrument was 62 percent. Cases in the RIA sample were assigned a weight based on the sampling design and their probability of being selected, ensuring a sample that was representative of American adults aged

\footnotetext{
${ }^{3}$ Though this is the term used by GfK, the data are cross-sectional and do not represent a "panel" in a longitudinal sense.

${ }^{4}$ Unlike other Internet research panels sampling only individuals with Internet access who volunteer for research, this panel was based on a sampling frame which included both listed and unlisted numbers, those without a landline telephone and was not limited to current Internet users or computer owners, and did not accept self-selected volunteers. An evaluation of the Knowledge Networks' Internet probability sample survey methodology compared favorably to online nonprobability samples as well as random-digit-dial telephone surveys (Chang and Krosnick 2009).
} 
18-60. These sample weights are used in all analyses. For a more comprehensive discussion of sampling and data collection procedures, see Litschi et al. (2014). Because this study focuses on the responses of Americans who had been heterosexually married ${ }^{5}$ and divorced, the analyses focused on the 3,023 respondents who answered the RIA survey question about which spouse wanted the divorce, and the 2,124 respondents who provided specific reasons for why they got a divorce.

\subsection{Measures}

\subsubsection{Retrospective Accounts of the Divorce}

The outcomes for this study are measures tapping respondents' retrospective interpretations of their divorce. For the first measure, respondents were asked to "choose the best answer that describes how (their most recent) marriage ended." Respondents were given five options, including (1) "I wanted the marriage to end, but my spouse did not," (2) I wanted it to end more than my spouse did," (3) "We both wanted it to end," (4) "My spouse wanted it to end more than I did," and (5) "My spouse wanted the marriage to end, but I did not." Higher scores on the question indicate that the divorce-at least in the respondent's view-was initiated and pursued by the former-spouse rather than the respondent. Because the measure has five values, I use ordinary least squares (OLS) regression for the analysis.

For respondents who chose options 1,2, or 3 for the previous question (indicating that either they or both they and their former-spouse wanted the divorce for whatever reasons), the RIA survey also asked, "For which of the following reasons did you want a divorce?" The RIA

\footnotetext{
${ }^{5}$ While the RIA does not ask respondents about whether their most recent marriage was heterosexual or homosexual, to increase the likelihood that divorced respondents were in heterosexual marriages, I excluded men and women who indicated in the RIA that they had never had sex with someone of the opposite sex. In ancillary analyses, I also excluded respondents who reported any homosexual relationships either at all or in the past 12 months. While these changes lowered the sample size, they did not change the substantive findings for the main analyses.
} 
then provided 17 different reasons, to which respondents could indicate yes $=1$, or no $=0$. Respondents could answer "yes" to as many reasons as appropriate. In order to observe patterns in the ways religious factors were associated with different reasons for divorce, I grouped the reasons into (1) those that clearly placed the blame largely with the respondent's former-spouse (e.g., "Spouse's pornography use" or "Spouse's immaturity"); (2) those in which the blame was placed more on the respondent (e.g., "I wanted to pursue a different life" or "My own romantic or sexual relationship with someone else"); and (3) those in which other circumstances are identified and/or the blame is unclear (e.g., "Problems with spouse's family" or "we married too young"). Because the reasons differ so greatly for male and female respondents (e.g., almost no men reported wanting a divorce because of their former-spouse's pornography use), along with models for the full sample, I also estimate separate regression models by gender to predict the likelihood that respondents affirmed a particular reason. Because the outcomes are dichotomous, I use binary logistic regression models to predict each.

Lastly, based on the different categories of "divorce reasons" described in the previous paragraph, I create three additive indexes using the three groups of RIA questions in which respondents primarily blame their former-spouse (called "blame ex"), where they blame themselves ("blame self"), or blame circumstances or some other factor ("blame circumstances"). Though each index has a different value range because of the different number of questions falling into each, I standardize each as Z-scores to make coefficients comparable across models. Because each has multiple values, I use OLS regression as my model estimation procedure.

\subsubsection{Religion Variables}


The key independent variables for the analysis are respondents' religious affiliation, the importance of religion in the respondent's life, and their frequency of religious service attendance. Because my interest is in the differences between conservative Protestants and others in the reasons they affirm for divorce, I created a dummy variable using the following information. Respondents were first asked their general religious affiliation. Those who chose "Protestant” were given options of "fundamentalist," “evangelical," "mainline," "liberal," "Pentecostal," or "none of these." I collapsed respondents who identified as "fundamentalist," "evangelical," or "Pentecostal" into one "conservative Protestant" group coded 1 with other Americans coded 0 (Woodberry and Smith 1998). For importance of religion, respondents were asked, "How important (if at all) is religious faith to you?" Responses ranged from 1 = "not important at all" to $5=$ "more important than anything else," and I included this as a continuous measure. Lastly, respondents were asked, "How often, if ever, do you normally attend religious services?" Responses ranged from 1 = "never" to $8=$ "more than once a week," and this is also included as a continuous measure.

\subsubsection{Controls}

The analyses include a number of sociodemographic controls. For the full models, gender is included as a control variable (female $=1$, male $=0$ ). For all models, age is measured in years from 18 to 60. Dummy variables are included for marital status (married $=1$ ), parental status (any children $=1)$, race $($ white $=1$, other race $=0)$, and region $($ southern residence $=1$, elsewhere $=0$ ). Educational attainment is measured in categories from $1=$ less than high school to $4=$ bachelors degree or higher. And household income is measured with 19 values from $1=$ less than $\$ 5,000$ to $19=\$ 175,000$ or more. Table 1 presents descriptive information for all variables used in the analyses. 


\section{[TABLE 1 ABOUT HERE]}

\subsection{Plan of Analysis}

The analysis proceeds as follows. First, Table 2 presents OLS regression models predicting how much respondents attribute their most recent divorce to their former-spouse's initiation as opposed to their own. I include a full sample model and separate models for both men and women. Models present unstandardized regression coefficients and standard errors.

Tables 3 and 4 present binary logistic regression models predicting affirmative answers for each of the 17 listed reasons for getting a divorce in the RIA survey. In order to conserve space, the 17 outcomes variables are listed along the far left row and only key predictor variables (conservative Protestant affiliation, religious importance, religious service attendance, and gender) are listed across the top column. All models, however, include the full array of controls. Table 3 presents logistic regression models for the full sample. Table 4 presents outcomes with the sample split by gender due to drastically different response patterns for men and women.

Lastly, in order to provide a summary analysis for the trends observed in Tables 3 and 4 , I estimate religion's effect on each of the three additive indexes I constructed using the three groups of RIA questions: blame ex, blame self, and blame circumstances. I estimate OLS regression models for the full sample and men and women separately to examine the effects of religion measures on each of these outcomes with relevant controls in place.

\section{Results}

Table 2 presents OLS regression models predicting how much of the divorce respondents attribute to the initiation of their former-spouse versus their own. While those who are affiliated with conservative Protestantism or believe their religion is more important to them are no different from other Americans in this regard, those who attend religious services more 
frequently are significantly more likely to report that their former-spouse was the one who initiated the divorce, not them. Splitting the sample by gender shows that the coefficient for religious attendance points in the same direction for both men and women, though it is only marginally significant for men. Test for interaction effects (available upon request), however, found no significant interaction between gender and worship attendance, and thus, it is likely that the marginal significance for men is due to reduced sample size. Religious attendance, in other words, is similarly predictive of attributing the initiation of the divorce to one's former-spouse for both men and women.

\section{[TABLE 2 ABOUT HERE]}

How does religion predict specific reasons that respondents give for their divorce. Table 3 presents odds ratios from binary logistic regression models predicting each of the 17 reasons the RIA provided for why divorced respondents sought a divorce (those reported not seeking the divorce at all were not asked this question). Clearly, religiosity and conservative Protestant affiliation are simply not significantly associated with many of the provided reasons with controls in place. Some of the significant associations show inconsistent patterns, while others show discernable trends. Those affiliated with conservative Protestantism, for example, are less likely than other Americans to cite that they divorced their former-spouse because of their former-spouse's abandonment, obsession over career, or their being unresponsive to the respondent's needs. But conservative Protestant affiliates are more likely to report divorcing their former-spouse because of their pornography use or sexual/romantic infidelity (marginal), which suggests that sexual "cheating" may provide social justification for conservative Protestants to pursue divorce. 
The other two religion variables show more consistent associations with divorce accounts. Among the significant associations between various divorce reasons and religious importance, Americans who feel that religion is more important to them are always more likely than other Americans to choose responses that blame their former-spouse's mistakes or faults, never less likely. Specifically, Americans who report that religion is more important to them are more likely to affirm that they got a divorce because of their former-spouse's abandonment (marginal), sexual/romantic infidelity, physical abuse, or emotional abuse. They are also more likely to affirm that they got a divorce because of problems' with their former-spouse's family.

Religious service attendance shows a similar trend, but is significant for a different set of outcomes. Those who attend worship services more frequently are not significantly more likely to choose divorce reasons that blame their former-spouse, but they are significantly less likely than other Americans to affirm any of the reasons that blame themselves for the divorce. People who attend worship services more frequently are less likely to say that they got a divorce because of their own sexual/romantic infidelity, because they were tired of making a bad match work, or because they wanted to pursue a different life path. They also appear to be less likely than other Americans to select divorce reasons that either blame circumstances or leave blame unclear.

The last column shows the association between being female and choosing various divorce reasons, suggesting significant contrasts between how women and men account for their split in retrospect. Women are more likely than men to cite their former-spouse's immaturity, pornography use, physical and emotional abuse, unresponsiveness to their needs, and substance abuse. Conversely, women are less likely than men to say the got a divorce because they married too young or they had insurmountable cultural or religious differences.

[TABLE 3 ABOUT HERE] 
Given these stark contrasts between the ways women and men select reasons for their divorce, how might the associations between religious factors and divorce reasons differ by gender? Results from Table 4 show that much of the core trends remain the same, namely, men and women who believe religion is more important to them are more likely to select divorce reasons that blame the former-spouse for the divorce, while women who attend religious services more frequently are significantly less likely to select reasons that blame themselves.

Interesting gender differences turn up for conservative Protestants, however. Conservative Protestant men, for example, are more likely than others to say they divorced their former-spouse because of her romantic/sexual infidelity, while conservative Protestant women are more likely to say they divorced their former-spouse because of his pornography use. Again, this likely suggests a central role that sexual fidelity plays in the conservative Protestant subculture not only within relationships, but in justifying divorces.

\section{[TABLE 4 ABOUT HERE]}

The regression analyses in Table 5 allow me to summarize the trends observed in Tables 3 and 4 by predicting affirmative responses for each group of divorce reasons, namely, those that: blame the former-spouse, blame the respondent, or blame circumstances. While conservative Protestants, either in the full sample or for men and women separately, are not consistently associated with patterns of responses, there are again clear patterns of associations for religious importance and religious service attendance. Specifically, men and women who believe that religion is more important to them are more likely to affirm divorce reasons that place the blame with the former-spouse. Men with higher religious importance are also more likely than other men to blame their circumstances. In contrast, men and women who attend 
religious services more often are less likely than others to affirm divorce reasons that blame themselves, and frequent male attendees are also less likely to blame their circumstances.

\section{[TABLE 5 ABOUT HERE]}

\section{Discussion and Conclusions}

This article sought to test whether religion predicted the ways divorced Americans account for their divorce retrospectively. Building on Mills's (1940) "vocabularies of motive" concept, I reasoned that actors tend to give "accounts" that situate their past behaviors or experiences in ways that will be socially appropriate for their reference groups. Because Americans who are more deeply imbedded within theologically conservative communities would be more likely to face social stigma or internalized shame for a divorce (Jenkins 2010, 2014; Konstam et al. 2016), I hypothesized that religious commitment and theological conservatism would be associated with Americans seeking to frame their divorce in ways that place the blame on their former-spouse, and, correspondingly, deflect blame from themselves. Drawing on a unique, large, and representative sample of divorced Americans, and examining a variety of potential reasons that people give for seeking a divorce, the analyses have generally affirmed these expectations. Specifically, men and women who attend religious services more frequently are more likely to say that their former-spouse initiated the divorce rather than them, and even among those who affirm that they sought the divorce, those who attend worship services more often are always less likely to affirm reasons for divorce that blame themselves. Conversely, men and women for whom religion is more important are consistently more likely to affirm divorce reasons that lay the blame on their former-spouse's flaws or mistakes, and never their own.

The findings from this study contribute to our understanding of religion and divorce in several important ways. While there has been a tremendous amount of research on the religious 
correlates of divorce, the current study has extended this literature by examining how religion influences the ways divorcées think about-or at least report about-their divorce in hindsight. Importantly, previous research on religion in the lives of divorcées emphasized the importance of religious practice and belief in re-imagining or re-creating a new self in light of one's religious identity (Jenkins 2010, 2014; Simonič and Klobučar's 2017). Findings from this study suggest that this may extend to the ways religious individuals process their divorce socially. While some divorced Americans report backing away from religious community after the divorce for fear of judgment or stigma (Brown 2015; Konstam et al. 2016; Sullivan 2012), the fact that religiouslycommitted Americans in my study were more likely to portray their former-spouse as the initiator of the divorce and blame their former-spouse's faults, while also being less likely to cite their own contribution to the divorce, suggests that some divorcées may deal with potential stigma or shame by re-articulating their divorce in ways that deflect blame or guilt. This would be completely consistent with the "vocabularies of motive" idea since religious actors would naturally want to explain their experience in a way that is consistent with the moral evaluations of their religious community and their own self-concept.

The findings also showed that these trends tend to hold across gender. While there were certainly some gendered patterns in the reasons divorcées cited for their divorce (e.g., women were far more likely to cite physical or emotional abuse as a reason for divorce, and men almost never affirmed divorcing their former-spouse because of her pornography use), religious commitment seemed to predict similar patterns in the divorce reasons that respondents affirmed. For men and women alike, religious attendance predicted a greater likelihood of reporting that a respondent's former-spouse wanted the divorce more than they did; religious importance was positively associated with citing divorce-reasons that blamed the former-spouse; and worship 
attendance was negatively associated with affirming reasons that blamed the respondent. Thus, religion's influence on the retrospective divorce accounts of respondents seems to transcend gender, despite the fact that those reasons are themselves highly gendered.

Interestingly, while religious importance and religious service attendance were both consistently associated with divorce reasons, the association between conservative Protestantism and divorce reasons was less consistent. Sometimes conservative Protestant men and women were more likely to blame the divorce on certain faults or flaws in the former-spouse, while other times they were less likely to do so. Among the consistent findings for conservative Protestants-in line with my earlier expectations-was that they were never more likely than other Americans to cite reasons that blamed themselves for their divorce.

Another interesting finding for conservative Protestantism was the gendered patterns of citing reasons for divorce that blamed the former-spouse's pornography use (for women) or sexual/relational infidelity (for men). This is likely because sexual infidelity is often thought of as one of the only "biblical" grounds for divorce within conservative Protestant communities. Jesus cited marital unfaithfulness as the only exception clause to the rule that his followers should not divorce and remarry (Matthew 5:32, 19:9). And because Jesus could be interpreted as considering lustful gazes and thoughts as analogous (or even equal to) physical adultery (Matthew 5:28), some conservative Protestants have also argued that habitual pornography use might also be grounds for divorce (Gilkerson 2015). Consequently, even though married conservative Protestants by and large are statistically less likely than other Americans to commit adultery (Burdette et al. 2007) or view pornography (Perry 2017b), conservative Protestants may be more inclined to emphasize these reason for divorce since they are the ones most socially legitimate within that religious tradition. 
Before concluding, several data limitations should also be acknowledged to chart a path for future research. First, given these data, this article can make no claim that the reasons respondents cite for their divorce were the actual contributing factors to that divorce. The vocabularies of motive framework allows me to sidestep that problem theoretically by focusing on the accounts themselves rather than the actual divorce. However, to the extent that the reasons cited by respondents reflect the actual situation as it happened, the connection between religion and the divorce could be different. That is, persons who are more deeply religious might actually be less likely to initiate the divorce, and perhaps, even when they are involved in initiating the divorce, could be less likely to contribute to the failure of the marriage than their former-spouse. The data unfortunately to not allow me to confirm whether this is in fact the case. A possible solution to this problem for future studies would be to use dyadic data, where both formerspouses are interviewed about their divorce experience and researchers could check to confirm whether the associations between religion and respondents' retrospective reasons for divorce correspond to those given by their former-spouse. Another potential limitation is the limited number of religion measures. While religious importance, religious attendance, and religious affiliation are indeed core measures often used by religion scholars, other useful measures not included in the RIA would be a measure of biblical literalism, which is often found to powerfully predict attitudes toward divorce (Ellison, Wolfinger, and Ramos-Wada 2012; Martin and Parashar 2006; Stokes and Ellison 2010). Another helpful measure would be a more direct question regarding how one's religious community actually feels about divorce in general or their divorce specifically.

It is worth speculating briefly about whether the observed associations in this study may change over time. Despite increasing acceptance of divorce in the United States (Stokes and 
Ellison 2010), it still remains a stigmatizing situation, and particularly for those within religious communities (Jenkins 2010, 2014; Konieczny 2016; Konstam et al. 2016; Simonič and Klobučar 2017; Sullivan 2012). Focusing on the explanations divorcées cite for their divorce suggests that religious individuals may mitigate some of that social stigma or shame by deflecting blame from themselves and toward their former-spouse. To the extent that being within a "pro-marriage" community means also being in an "anti-divorce" community, the observed association between religion and reasons for divorce may remain consistent. However, as Konieczny (2016) points out, an increasing number of conservative Christian congregations are seeking to introduce new ministries targeting disrupted families and seeking to erase the shame divorced adherents may feel. This may point to a gradual decoupling of the "pro-marriage" stance from the perception of being more hostile to divorce (and divorcées) in more faith communities. 


\section{References}

Amato, Paul R. 2010. "Research on Divorce: Continuing Trends and New Developments." Journal of Marriage and Family 72:650-666.

Amato, Paul R., and Stacy J. Rogers. 1997. “A Longitudinal Study of Marital Problems and Subsequent Divorce." Journal of Marriage and Family 59(3):612-624.

Barna Group. 2001. "Born Again Adults Less Likely to Co-Habit, Just as Likely to Divorce." August 6. https://www.barna.com/research/born-again-adults-less-likely-to-co-habit-justas-likely-to-divorce/.

Barna Group. 2004. "Born Again Christians As Likely to Divorce as Are Non-Christians." September 8. https://www.barna.com/research/born-again-christians-just-as-likely-todivorce-as-are-non-christians/.

Barna Group. 2008. "New Marriage and Divorce Statistics Released.” March 31. https://www.barna.org/barna-update/family-kids/42-new-marriage-and-divorce-statisticsreleased\#.Vplht_krKUm.

Brown, Edna, Terri L. Orbuch, and Jose A. Bauermeister. 2008. "Religiosity and Marital Stability among Black American and White American Couples.” Family Relations 57(2):187-197.

Brown, Matthew. 2015. "20 Percent of Church-goers No Longer Attend Church After a Divorce." Deseret News. November 2. https://www.deseretnews.com/article/865640436/20-percent-of-churchgoers-no-longerattend-church-after-a-divorce-2-and-the-loss-among-children-is.html.

Bulanda, Jennifer Roebuck, and Susan L. Brown. 2007. "Race-ethnic Differences in Marital Quality and Divorce." Social Science Research 36(3):945-967. 
Burdette, Amy C., Christopher G. Ellison, Darren E. Sherkat, and Kurt A. Gore. 2007. “Are There Religious Variations in Marital Infidelity?” Journal of Family Issues 28(12):15531581.

Burke, Kenneth. 1969. A Grammar of Motives. Berkeley, CA: University of California Press. Call, Vaughn R. A., and Tim B. Heaton. 1997. "Religious Influence on Marital Stability." Journal for the Scientific Study of Religion 36(3):382-392.

Chang, Linchiat, and Jon A. Krosnick. 2009. "National Surveys Via Rdd Telephone Interviewing Versus the Internet: Comparing Sample Representativeness and Response Quality.” Public Opinion Quarterly 73(4):641-678.

Chi, S. K., and Sharon K. Houseknecht. 1985. "Protestant Fundamentalism and Marital Success: A Comparative Approach.” Sociology and Social Research 69:351-74.

Clydesdale, Timothy T. 1997. "Family Behaviors among Early U.S. Baby Boomers: Exploring the Effects of Religion and Income Change, 1965-1982. Social Forces 76(2):605-635.

Edgell, Penny. 2006. Religion and Family in a Changing Society. Princeton, NJ: Princeton University Press.

Ellison, Christopher G., Nicholas H. Wolfinger, and Aida I. Ramos-Wada. 2012. "Attitudes toward Marriage, Divorce, Cohabitation, and Casual Sex Among Working-Age Latinos: Does Religion Matter? Journal of Family Issues 34(3):295-322.

Gerstel, Naomi. 1987. “Divorce and Stigma.” Social Problems 34(2):172-186.

Gilkerson, Luke. 2015. "Porn Use as Grounds for Divorce: How My Opinion Changed.” Covenant Eyes. October 8. http://www.covenanteyes.com/2015/10/08/porn-use-asgrounds-for-divorce-how-my-opinion-changed/.

Glass, Jennifer, and Philip Levchak. 2014. "Red States, Blue States, and Divorce: Understanding 
the Impact of Conservative Protestantism on Regional Variation in Divorce Rates.” American Journal of Sociology 119:1002-1046.

Glenn, Noval D., and Michael Supancic. 1984. "The Social and Demographic Correlates of Divorce and Separation in the United States: An Update and Reconsideration." Journal of Marriage and Family 46(3):563-575.

Gray, Mark M. 2013. "Divorce Still Less Likely among Catholics." http://nineteensixty-four.blogspot.ca/2013/09/divorce-still-less-likely-among.html.

Heaton, Tim B., and Edith L. Pratt. 1990. "The Effects of Religious Homogamy on Marital Satisfaction and Stability.” Journal of Family Issues 11(2):191-207.

Jenkins, Kathleen E. 2010. "In Concert and Alone: Divorce and Congregational Experience." Journal for the Scientific Study of Religion 49(2):278-292.

Jenkins, Kathleen E. 2005. Awesome Families: The Promise of Healing Relationships in the International Churches of Christ. New Brunswick, NJ: Rutgers University Press.

Jenkins, Kathleen E. 2014. Sacred Divorce: Religion, Therapeutic Culture, and Ending Life Partnerships. New Brunswick, NJ: Rutgers University Press.

Konieczny, Mary Ellen. 2016. "Individualized Marriage and Family Disruption Ministries in Congregations: How Culture Matters." Sociology of Religion 77(2):144-170.

Konstam, Varda, Samantha Karwin, Teyana Curran, Meaghan Lyons, and Selda Celen-Demirtas. 2016. "Stigma and Divorce: A Relevant Lens for Emerging and Young Adults." Journal of Divorce \& Remarriage 57(3):173-194.

Lehrer, Evelyn L. 2004. "Religion as a Determinant of Economic and Demographic Behavior in the United States." Population and Development Review 30(4):707-726.

Lehrer, Evelyn L., and Carmel U. Chiswick. 1993. "Religion as a Determinant of Marital 
Stability." Demography 30(3):385-404.

Lehrer, Evelyn L., and Yeon Son. 2017. "Marital Instability in the United States: Trends, Driving Forces, and Implications for Children." IZA Institute for Labor Ecomomics DP No. 10503.

Levitt, Heidi M., and Kimberly N. Ware. 2006. “Religious Leaders’ Perspectives on Marriage, Divorce, and Intimate Partner Violence." Psychology of Women Quarterly 30(2):212222.

Litchi, Andrew, David Gordon, Austin Porter, Mark Regnerus, Jane Ryngaert, and Larissa Sarangaya. 2014. "Relationships in American Survey.” The Austin Institute for the Study of Family and Culture. http://relationshipsinamerica.com/.

Mahoney, Annette. 2010. "Religion in Families, 1999-2009: A Relational Spirituality Framework." Journal of Marriage and Family 72(4):805-827.

Mahoney, Annette, Kenneth I. Pargament, Nalina Tarakeshwar, and Aaron B. Swank. 2001. "Religion in the Home in the 1980s and 1990s: A Meta-Analytic Review and Conceptual Analysis of Links between Religion, Marriage, and Parenting." Journal of Family Psychology 15(4):559-596.

Martin, Steven P., and Sangeeta Parashar. 2006. “Women's Changing Attitudes toward Divorce, 1974-2002: Evidence for an Educational Crossover.” Journal of Marriage and Family 68(1):29-40.

Massoglia, Michael, Brianna Remster, and Ryan D. King. 2011. "Understanding the Incarceration-Divorce Relationship.” Social Forces 90(1):133-155.

Mills, C. Wright. 1940. "Situated Actions and Vocabularies of Motive." American Sociological Review 5(6):904-913. 
Mullins, Larry C., Kimberly P. Brackett, Donald W. Bogie, and Daniel Pruett. 2006. "The Impact of Concentrations of Religious Denominational Affiliations on the Rate of Currently Divorced in Counties in the United States." Journal of Family Issues 27:9761000.

Perry, Samuel L. 2017a. Growing God's Family: The Global Orphan Care Movement and the Limits of Evangelical Activism. New York: NYU Press.

Perry, Samuel L. 2017b. “Spousal Religiosity, Religious Bonding, and Pornography Consumption." Archives of Sexual Behavior 46(2):561-574.

Perry, Samuel L. 2018. "Pornography Use and Marital Separation: Evidence from Two-Wave Panel Data." Archives of Sexual Behavior. doi: 10.1007/s10508-017-1080-8.

Piper, John. 2009. This Momentary Marriage: A Parable of Permanence. Wheaton, IL: Crossway.

Simonič, Barbara, and Nataša Rijavec Klobučar. 2017. "Experiencing Positive Religious Coping in the Process of Divorce: A Qualitative Study." Journal of Religion and Health 56(5):1644-1654.

Stokes, Charles, and Christopher G. Ellison. 2010. "Religion and Attitudes toward Divorce Laws among U.S. Adults.” Journal of Family Issues 31(10):1279-1304.

Sullivan, Susan Crawford. 2012. Living Faith: Everyday Religion and Mothers in Poverty. Chicago, IL: University of Chicago Press.

Sweezy, Kate, and Jill Tiefenthaler. 1996. "Do State-Level Variables Affect Divorce Rates?" Review of Social Economy 1:46-65.

Vaaler, Margaret, Christopher G. Ellison, and Daniel A. Powers. 2009. "Religious Influences on the Risk of Marital Dissolution.” Journal of Marriage and Family 71(4):917-934. 
Van Biema, David. 2007. “An Evangelical Rethink on Divorce?” Time Magazine. November 7. http://content.time.com/time/printout/0,8816,1680709,00.html.

Weaver, Andrew J., Judith A. Samford, Virginia J. Morgan, David B. Larson, Harold G. Koenig, and Kevin J. Flannely. 2002. “A Systematic Review of Research on Religion in Six Primary Marriage and Family Journals: 1995-1999." American Journal of Family Therapy 30(4):293-309.

Wilcox, W. Bradford. 2004. Soft Patriarchs, New Men. How Christianity Shapes Fathers and Husbands. Chicago, IL: University of Chicago Press.

Wilcox, W. Bradford. 2009. "How Focused on the Family? Evangelical Protestants, the Family, and Sexuality." Pp. 251-275 in Evangelicals and Democracy in America, vol. 1, edited by Steve Brint and Jean R. Schroedel. New York: Russell Sage.

Wilcox, W. Bradford, and Nicholas H. Wolfinger 2016. Soul Mates: Religion, Sex, Love, and Marriage among African Americans and Latinos. New York: Oxford University Press. Woodberry, Robert D., and Christian Smith. 1998. "Fundamentalism et al: Conservative Protestants in America." Annual Review of Sociology 24:25-56. 
Table 1: Descriptive statistics

\begin{tabular}{|c|c|c|c|c|c|c|c|}
\hline \multirow[b]{2}{*}{ Variables } & \multirow[b]{2}{*}{ Range } & \multicolumn{2}{|l|}{ Full Sample } & \multicolumn{2}{|l|}{ Men } & \multicolumn{2}{|l|}{ Women } \\
\hline & & Mean or \% & SD & Mean or $\%$ & SD & Mean or $\%$ & SD \\
\hline How much of divorce was former-spouse's initiation? & $1-5$ & 2.7 & 1.4 & 3.2 & 1.3 & 2.4 & 1.3 \\
\hline \multicolumn{8}{|l|}{ Reasons for Divorce } \\
\hline \multicolumn{8}{|l|}{ Blame More With Former-spouse } \\
\hline Spouse's Immaturity & $0-1$ & $30 \%$ & & $26 \%$ & & $32 \%$ & \\
\hline Abandonment & $0-1$ & $7 \%$ & & $6 \%$ & & $8 \%$ & \\
\hline Spouse's Pornography Use & $0-1$ & $5 \%$ & & $1 \%$ & & $8 \%$ & \\
\hline Spouse's romantic/sexual infidelity & $0-1$ & $29 \%$ & & $31 \%$ & & $28 \%$ & \\
\hline Physical abuse & $0-1$ & $15 \%$ & & $7 \%$ & & $20 \%$ & \\
\hline Spouse's career came before family & $0-1$ & $5 \%$ & & $5 \%$ & & $5 \%$ & \\
\hline Emotional abuse & $0-1$ & $28 \%$ & & $13 \%$ & & $37 \%$ & \\
\hline Spouse unresponsive to my needs & $0-1$ & $33 \%$ & & $30 \%$ & & $35 \%$ & \\
\hline Alcohol or drug use & $0-1$ & $24 \%$ & & $14 \%$ & & $29 \%$ & \\
\hline Revelations from spouse's past & $0-1$ & $5 \%$ & & $4 \%$ & & $5 \%$ & \\
\hline \multicolumn{8}{|l|}{ Blame More With Respondent } \\
\hline My own romantic/sexual infidelity & $0-1$ & $12 \%$ & & $11 \%$ & & $12 \%$ & \\
\hline Grew tired of making a poor match work & $0-1$ & $31 \%$ & & $33 \%$ & & $30 \%$ & \\
\hline I wanted to pursue different life & $0-1$ & $17 \%$ & & $16 \%$ & & $17 \%$ & \\
\hline \multicolumn{8}{|l|}{ Circumstances at Fault /Blame Unclear } \\
\hline Problems with Spouse's Family & $0-1$ & $15 \%$ & & $15 \%$ & & $15 \%$ & \\
\hline Insurmountable cultural/religious differences & $0-1$ & $5 \%$ & & $6 \%$ & & $4 \%$ & \\
\hline We married too young & $0-1$ & $21 \%$ & & $24 \%$ & & $19 \%$ & \\
\hline Different financial priorities/spending patterns & $0-1$ & $25 \%$ & & $25 \%$ & & $25 \%$ & \\
\hline \multicolumn{8}{|l|}{ Independent Variables } \\
\hline Conservative Protestant & $0-1$ & $15 \%$ & & $16 \%$ & & $14 \%$ & \\
\hline Importance of Religion & $1-5$ & 3.3 & 1.2 & 3 & 1.3 & 3.4 & 1.1 \\
\hline Religious Service Attendance & $1-8$ & 3.3 & 2.5 & 3.1 & 2.5 & 3.4 & 2.5 \\
\hline Female & $0-1$ & $64 \%$ & & & & & \\
\hline Age & $18-60$ & 48 & 8.8 & 48 & 8.5 & 48 & 8.9 \\
\hline Married & $0-1$ & $51 \%$ & & $57 \%$ & & $48 \%$ & \\
\hline Any Children & $0-1$ & $78 \%$ & & $75 \%$ & & $80 \%$ & \\
\hline Educational Attainment & $1-4$ & 2.7 & .9 & 2.7 & .9 & 2.7 & .9 \\
\hline Household Income & $1-19$ & 11.8 & 4.4 & 12.2 & 4.4 & 11.4 & 4.3 \\
\hline White & $0-1$ & $70 \%$ & & $65 \%$ & & $73 \%$ & .45 \\
\hline Southern Residence & $0-1$ & $44 \%$ & & $44 \%$ & & $44 \%$ & .50 \\
\hline
\end{tabular}

Source: 2014 Relationships in America Survey. 
Table 2: Ordinary least squares regression predicting how much a respondent attributes their most recent divorce to their former-spouse's initiation.

\begin{tabular}{|c|c|c|c|}
\hline Predictors & Full Sample & Men only & Women only \\
\hline Conservative Protestant & $\begin{array}{l}.06 \\
(.07)\end{array}$ & $\begin{array}{l}.02 \\
(.10)\end{array}$ & $\begin{array}{l}.11 \\
(.10)\end{array}$ \\
\hline Importance of Religion & $\begin{array}{l}.04 \\
(.03)\end{array}$ & $\begin{array}{l}.03 \\
(.04)\end{array}$ & $\begin{array}{l}.05 \\
(.04)\end{array}$ \\
\hline Religious Service Attendance & $\begin{array}{l}.04 * * * \\
(.01)\end{array}$ & $\begin{array}{l}.03+ \\
(.02)\end{array}$ & $\begin{array}{l}.05 * * \\
(.02)\end{array}$ \\
\hline Female & $\begin{array}{l}-.83^{* * * *} \\
(.05)\end{array}$ & & \\
\hline Age & $\begin{array}{l}.01 \\
(.00)\end{array}$ & $\begin{array}{l}.02 * * * \\
(.00)\end{array}$ & $\begin{array}{l}-.01 \\
(.00)\end{array}$ \\
\hline Married & $\begin{array}{l}-.17 * * * \\
(.05)\end{array}$ & $\begin{array}{l}-.14+ \\
(.08)\end{array}$ & $\begin{array}{l}-.20 * * \\
(.07)\end{array}$ \\
\hline Any Children & $\begin{array}{l}.06 \\
(.06)\end{array}$ & $\begin{array}{l}.10 \\
(.09)\end{array}$ & $\begin{array}{l}-.02 \\
(.08)\end{array}$ \\
\hline Educational Attainment & $\begin{array}{l}-.01 \\
(.03)\end{array}$ & $\begin{array}{l}-.03 \\
(.04)\end{array}$ & $\begin{array}{l}-.01 \\
(.04)\end{array}$ \\
\hline Household Income & $\begin{array}{l}-.01 \\
(.01)\end{array}$ & $\begin{array}{l}-.01 \\
(.01)\end{array}$ & $\begin{array}{l}-.01 \\
(.01)\end{array}$ \\
\hline White & $\begin{array}{l}.21 * * * \\
(.05)\end{array}$ & $\begin{array}{l}.27 * * * \\
(.08)\end{array}$ & $\begin{array}{l}.16^{*} \\
(.08)\end{array}$ \\
\hline Southern Residence & $\begin{array}{l}-.03 \\
(.05)\end{array}$ & $\begin{array}{l}-.05 \\
(.07)\end{array}$ & $\begin{array}{l}-.02 \\
(.07)\end{array}$ \\
\hline Constant & $\begin{array}{l}2.68 * * * \\
(.18)\end{array}$ & $\begin{array}{l}2.14 * * * \\
(.26)\end{array}$ & $\begin{array}{l}2.22 * * * \\
(.24)\end{array}$ \\
\hline $\begin{array}{l}\text { Adjusted R } \\
\mathrm{N}\end{array}$ & $\begin{array}{l}.10 \\
3,023 \\
\end{array}$ & $\begin{array}{l}.02 \\
1,337 \\
\end{array}$ & $\begin{array}{l}.02 \\
1,686 \\
\end{array}$ \\
\hline
\end{tabular}

Source: 2014 Relationships in America Survey.

Note: Odds ratios with standard errors in parentheses.

$+p<.10 ; * p<.05 ; * * p<.01 ; * * * p<.001$ (two-tailed test). 
Table 3: Binary logistic regression models predicting retrospective reasons for divorce (full sample).

\begin{tabular}{|c|c|c|c|c|}
\hline \multirow[b]{2}{*}{ Outcome: Reasons for divorce } & \multicolumn{4}{|c|}{ Key Predictors } \\
\hline & Cons. Prot. & Importance & Attendance & Female \\
\hline \multicolumn{5}{|l|}{ Blame More With Former-spouse } \\
\hline Spouse’s Immaturity & $\begin{array}{l}.81 \\
(.15)\end{array}$ & $\begin{array}{l}1.01 \\
(.05)\end{array}$ & $\begin{array}{l}.98 \\
(.03)\end{array}$ & $\begin{array}{l}1.32 * * \\
(.11)\end{array}$ \\
\hline Abandonment & $\begin{array}{l}.46^{*} \\
(.32)\end{array}$ & $\begin{array}{l}1.18+ \\
(.10)\end{array}$ & $\begin{array}{l}1.00 \\
(.04)\end{array}$ & $\begin{array}{l}1.04 \\
(.19)\end{array}$ \\
\hline Spouse's Pornography Use & $\begin{array}{l}1.75^{*} \\
(.28)\end{array}$ & $\begin{array}{l}1.05 \\
(.11)\end{array}$ & $\begin{array}{l}1.03 \\
(.05)\end{array}$ & $\begin{array}{l}9.31 * * * \\
(.41)\end{array}$ \\
\hline Spouse's romantic/sexual infidelity & $\begin{array}{l}1 . .26+ \\
(.14)\end{array}$ & $\begin{array}{l}1.12 * \\
(.05)\end{array}$ & $\begin{array}{l}1.00 \\
(.02)\end{array}$ & $\begin{array}{l}.85 \\
(.10)\end{array}$ \\
\hline Physical abuse & $\begin{array}{l}.81 \\
(.19)\end{array}$ & $\begin{array}{l}1.31^{* * * *} \\
(.07)\end{array}$ & $\begin{array}{l}.99 \\
(.03)\end{array}$ & $\begin{array}{l}3.02 * * * \\
(.16)\end{array}$ \\
\hline Spouse's career came before family & $\begin{array}{l}.36^{*} \\
(.42)\end{array}$ & $\begin{array}{l}.95 \\
(.11)\end{array}$ & $\begin{array}{l}1.05 \\
(.05)\end{array}$ & $\begin{array}{l}1.18 \\
(.22)\end{array}$ \\
\hline Emotional abuse & $\begin{array}{l}1.01 \\
(.15)\end{array}$ & $\begin{array}{l}1.23 * * * \\
(.06)\end{array}$ & $\begin{array}{l}1.00 \\
(.03)\end{array}$ & $\begin{array}{l}3.56^{* * * *} \\
(.13)\end{array}$ \\
\hline Spouse unresponsive to my needs & $\begin{array}{l}.71^{*} \\
(.15)\end{array}$ & $\begin{array}{l}.97 \\
(.05)\end{array}$ & $\begin{array}{l}1.00 \\
(.02)\end{array}$ & $\begin{array}{l}1.24^{*} \\
(.10)\end{array}$ \\
\hline Alcohol or drug use & $\begin{array}{l}1.00 \\
(.16)\end{array}$ & $\begin{array}{l}1.09 \\
(.06)\end{array}$ & $\begin{array}{l}.97 \\
(.03)\end{array}$ & $\begin{array}{l}2.36^{* * * *} \\
(.12)\end{array}$ \\
\hline Revelations from spouse's past & $\begin{array}{l}.86 \\
(.35)\end{array}$ & $\begin{array}{l}1.08 \\
(.11)\end{array}$ & $\begin{array}{l}.94 \\
(.06)\end{array}$ & $\begin{array}{l}.99 \\
(.22)\end{array}$ \\
\hline Blame More With Respondent & & & & \\
\hline My own romantic/sexual infidelity & $\begin{array}{l}.86 \\
(.23)\end{array}$ & $\begin{array}{l}1.09 \\
(.07)\end{array}$ & $\begin{array}{l}.92 * \\
(.04)\end{array}$ & $\begin{array}{l}1.11 \\
(.15)\end{array}$ \\
\hline Grew tired of making a poor match work & $\begin{array}{l}.89 \\
(.15)\end{array}$ & $\begin{array}{l}.96 \\
(.05)\end{array}$ & $\begin{array}{l}.93 * * \\
.03)\end{array}$ & $\begin{array}{l}.89 \\
(.10)\end{array}$ \\
\hline I wanted to pursue different life & $\begin{array}{l}.96 \\
(.20)\end{array}$ & $\begin{array}{l}.95 \\
(.06)\end{array}$ & $\begin{array}{l}.89 * * * \\
(.03)\end{array}$ & $\begin{array}{l}1.13 \\
(.13)\end{array}$ \\
\hline Circumstances at Fault/Blame Unclear & & & & \\
\hline Problems with Spouse's Family & $\begin{array}{l}.80 \\
(.20)\end{array}$ & $\begin{array}{l}1.21 * * \\
(.07)\end{array}$ & $\begin{array}{l}.92 * \\
(.03)\end{array}$ & $\begin{array}{l}.95 \\
(.13)\end{array}$ \\
\hline Insurmountable cultural/religious differences & $\begin{array}{l}1.01 \\
(.31)\end{array}$ & $\begin{array}{l}1.02 \\
(.11)\end{array}$ & $\begin{array}{l}1.02 \\
(.05)\end{array}$ & $\begin{array}{l}.63^{*} \\
(.21)\end{array}$ \\
\hline We married too young & $\begin{array}{l}.96 \\
(.17)\end{array}$ & $\begin{array}{l}1.08 \\
(.06)\end{array}$ & $\begin{array}{l}.95+ \\
(.03)\end{array}$ & $\begin{array}{l}.71 * * \\
(.11)\end{array}$ \\
\hline Different financial priorities/spending patterns & $\begin{array}{l}.81 \\
(.16) \\
\end{array}$ & $\begin{array}{l}1.03 \\
(.06) \\
\end{array}$ & $\begin{array}{l}.95+ \\
(.03) \\
\end{array}$ & $\begin{array}{l}1.00 \\
(.11) \\
\end{array}$ \\
\hline
\end{tabular}

Source: 2014 Relationships in America Survey (N for all models = 2,124).

Note: Odds ratios with standard errors in parentheses. All models include variables for age, gender, marital status, parental status, educational attainment, Household income, race, southern residence, evangelical affiliation, importance of religion, and religious service attendance.

$+p<.10 ; * p<.05 ; * * p<.01 ; * * * p<.001$ (two-tailed test). 
Table 4: Binary logistic regression models predicting retrospective reasons for divorce.

\begin{tabular}{|c|c|c|c|c|c|c|}
\hline \multirow[b]{2}{*}{ Outcome: Reasons for divorce } & \multicolumn{3}{|c|}{ Men only $(\mathrm{N}=769)$} & \multicolumn{3}{|c|}{ Women only $(\mathrm{N}=1,355)$} \\
\hline & Cons. Prot. & Importance & Attendance & Cons. Prot. & Importance & Attendance \\
\hline \multicolumn{7}{|l|}{ Blame More With Former-spouse } \\
\hline Spouse's Immaturity & $\begin{array}{l}.67 \\
(.27)\end{array}$ & $\begin{array}{l}1.01 \\
(.08)\end{array}$ & $\begin{array}{l}.96 \\
(.04)\end{array}$ & $\begin{array}{l}.92 \\
(.19)\end{array}$ & $\begin{array}{l}1.01 \\
(.07)\end{array}$ & $\begin{array}{l}.99 \\
(.03)\end{array}$ \\
\hline Abandonment & $\begin{array}{l}.41 \\
(.58)\end{array}$ & $\begin{array}{l}1.37 * \\
(.16)\end{array}$ & $\begin{array}{l}.93 \\
(.08)\end{array}$ & $\begin{array}{l}.47^{*} \\
(.38)\end{array}$ & $\begin{array}{l}1.12 \\
(.12)\end{array}$ & $\begin{array}{l}1.04 \\
(.05)\end{array}$ \\
\hline Spouse's Pornography Use & $\begin{array}{l}\text { NA } \\
\text { NA }\end{array}$ & $\begin{array}{l}1.27 \\
(.44)\end{array}$ & $\begin{array}{l}1.02 \\
(.23)\end{array}$ & $\begin{array}{l}1.97 * \\
(.29)\end{array}$ & $\begin{array}{l}1.02 \\
(.12)\end{array}$ & $\begin{array}{l}1.03 \\
(.05)\end{array}$ \\
\hline Spouse's romantic/sexual infidelity & $\begin{array}{l}1.86^{* *} \\
(.24)\end{array}$ & $\begin{array}{l}1.21 * \\
(.08)\end{array}$ & $\begin{array}{l}.90^{*} \\
(.04)\end{array}$ & $\begin{array}{l}.97 \\
(.19)\end{array}$ & $\begin{array}{l}1.08 \\
(.07)\end{array}$ & $\begin{array}{l}1.05 \\
(.03)\end{array}$ \\
\hline Physical abuse & $\begin{array}{l}.37+ \\
(.53)\end{array}$ & $\begin{array}{l}1.20 \\
(.15)\end{array}$ & $\begin{array}{l}1.04 \\
(.07)\end{array}$ & $\begin{array}{l}.93 \\
(.21)\end{array}$ & $\begin{array}{l}1.36^{* * * *} \\
(.08)\end{array}$ & $\begin{array}{l}.97 \\
(.03)\end{array}$ \\
\hline Spouse's career came before family & $\begin{array}{l}.33+ \\
(.66)\end{array}$ & $\begin{array}{l}.80 \\
(.17)\end{array}$ & $\begin{array}{l}1.28 * * \\
(.09)\end{array}$ & $\begin{array}{l}.33+ \\
(.57)\end{array}$ & $\begin{array}{l}1.09 \\
(.14)\end{array}$ & $\begin{array}{l}.92 \\
(.07)\end{array}$ \\
\hline Emotional abuse & $\begin{array}{l}1.01 \\
(.32)\end{array}$ & $\begin{array}{l}1.13 \\
(.12)\end{array}$ & $\begin{array}{l}1.03 \\
(.06)\end{array}$ & $\begin{array}{l}1.01 \\
(.18)\end{array}$ & $\begin{array}{l}1.28 * * * \\
(.07)\end{array}$ & $\begin{array}{l}.99 \\
(.03)\end{array}$ \\
\hline Spouse unresponsive to my needs & $\begin{array}{l}1.10 \\
(.24)\end{array}$ & $\begin{array}{l}1.09 \\
(.08)\end{array}$ & $\begin{array}{l}.92 * \\
(.04)\end{array}$ & $\begin{array}{l}.53 * * \\
(.20)\end{array}$ & $\begin{array}{l}.89+ \\
(.07)\end{array}$ & $\begin{array}{l}1.05 \\
(.03)\end{array}$ \\
\hline Alcohol or drug use & $\begin{array}{l}1.72+ \\
(.31)\end{array}$ & $\begin{array}{l}1.10 \\
(.11)\end{array}$ & $\begin{array}{l}.82 * * * \\
(.06)\end{array}$ & $\begin{array}{l}.83 \\
(.19)\end{array}$ & $\begin{array}{l}1.09 \\
(.07)\end{array}$ & $\begin{array}{l}1.01 \\
(.03)\end{array}$ \\
\hline Revelations from spouse's past & $\begin{array}{l}.79 \\
(.56)\end{array}$ & $\begin{array}{l}1.19 \\
(.18)\end{array}$ & $\begin{array}{l}.97 \\
(.09)\end{array}$ & $\begin{array}{l}.89 \\
(.46)\end{array}$ & $\begin{array}{l}1.02 \\
(.14)\end{array}$ & $\begin{array}{l}.93 \\
(.07)\end{array}$ \\
\hline \multicolumn{7}{|l|}{ Blame More With Respondent } \\
\hline My own romantic/sexual infidelity & $\begin{array}{l}1.29 \\
(.32)\end{array}$ & $\begin{array}{l}1.16 \\
(.12)\end{array}$ & $\begin{array}{l}.97 \\
(.06)\end{array}$ & $\begin{array}{l}.57+ \\
(.34)\end{array}$ & $\begin{array}{l}1.02 \\
(.10)\end{array}$ & $\begin{array}{l}.91 * \\
(.05)\end{array}$ \\
\hline Grew tired of making a poor match work & $\begin{array}{l}1.05 \\
(.24)\end{array}$ & $\begin{array}{l}.96 \\
(.08)\end{array}$ & $\begin{array}{l}.94 \\
(.04)\end{array}$ & $\begin{array}{l}.79 \\
(.20)\end{array}$ & $\begin{array}{l}.95 \\
(.07)\end{array}$ & $\begin{array}{l}.92 * \\
(.03)\end{array}$ \\
\hline I wanted to pursue different life & $\begin{array}{l}.85 \\
(.31)\end{array}$ & $\begin{array}{l}1.11 \\
(.10)\end{array}$ & $\begin{array}{l}.92 \\
(.05)\end{array}$ & $\begin{array}{l}.95 \\
(.27)\end{array}$ & $\begin{array}{l}.86+ \\
(.08)\end{array}$ & $\begin{array}{l}.88 * * \\
(.04)\end{array}$ \\
\hline \multicolumn{7}{|l|}{ Circumstances at Fault/Blame Unclear } \\
\hline Problems with Spouse's Family & $\begin{array}{l}1.35 \\
(.29)\end{array}$ & $\begin{array}{l}1.22+ \\
(.11)\end{array}$ & $\begin{array}{l}.89 * \\
(.06)\end{array}$ & $\begin{array}{l}.51^{*} \\
(.30)\end{array}$ & $\begin{array}{l}1.18+ \\
(.09)\end{array}$ & $\begin{array}{l}.93+ \\
(.04)\end{array}$ \\
\hline Insurmountable cultural/religious differences & $\begin{array}{l}1.96+ \\
(.40)\end{array}$ & $\begin{array}{l}1.16 \\
(.17)\end{array}$ & $\begin{array}{l}.98 \\
(.08)\end{array}$ & $\begin{array}{l}.42 \\
(.59)\end{array}$ & $\begin{array}{l}.83 \\
(.16)\end{array}$ & $\begin{array}{l}1.08 \\
(.07)\end{array}$ \\
\hline We married too young & $\begin{array}{l}1.46 \\
(.25)\end{array}$ & $\begin{array}{l}1.40 * * * \\
(.09)\end{array}$ & $\begin{array}{l}.85 * * * \\
(.05)\end{array}$ & $\begin{array}{l}.61 * \\
(.24)\end{array}$ & $\begin{array}{l}.85^{*} \\
(.08)\end{array}$ & $\begin{array}{l}1.06 \\
(.04)\end{array}$ \\
\hline Different financial priorities/spending patterns & $\begin{array}{l}1.05 \\
(.26)\end{array}$ & $\begin{array}{l}1.10 \\
(.09)\end{array}$ & $\begin{array}{l}.88 * * \\
(.05)\end{array}$ & $\begin{array}{l}.68+ \\
(.21)\end{array}$ & $\begin{array}{l}.96 \\
(.07)\end{array}$ & $\begin{array}{l}1.00 \\
(.03)\end{array}$ \\
\hline
\end{tabular}

Source: 2014 Relationships in America Survey. Note: Odds ratios with standard errors in parentheses. All models include variables for age, marital status, parental status, educational attainment, Household income, race, southern residence, evangelical affiliation, importance of religion, and religious service attendance. $+p<.10 ; * p<.05 ; * * p<.01 ; * * * p<.001$ (two-tailed test). 
Table 5: Ordinary least squares regression predicting whether respondents are more likely to affirm reasons that mostly blame their former-spouse, themselves, or other circumstances for their divorce.

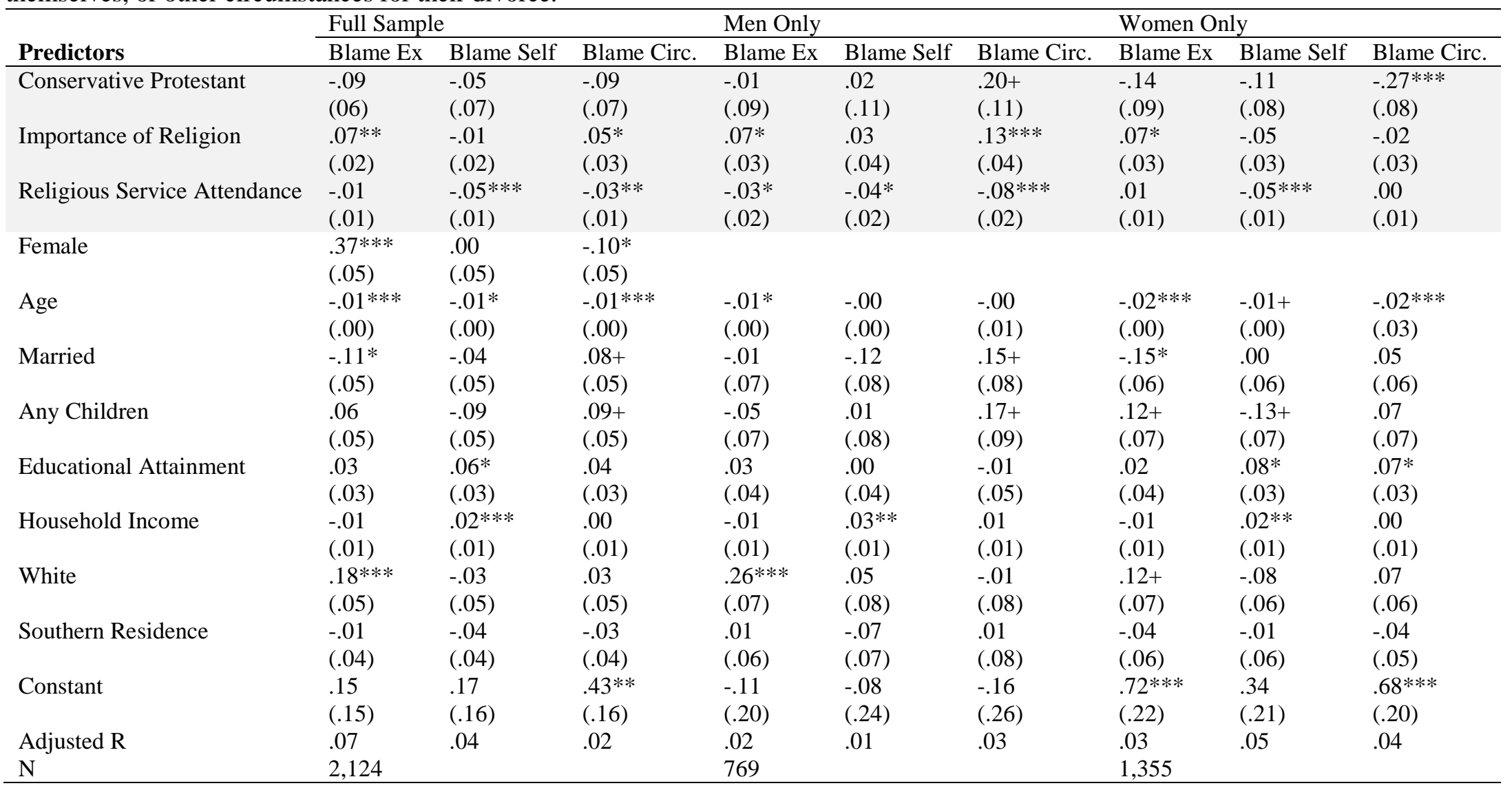

Source: 2014 Relationships in America Survey.

Note: Odds ratios with standard errors in parentheses.

$+p<.10 ; * p<.05 ; * * p<.01 ; * * * p<.001$ (two-tailed test). 